Research Paper

\title{
Bacaba beverage produced by Umutina Brazilian Amerindians: Microbiological and chemical characterization
}

\author{
Cláudia Puerari ${ }^{1}$, Karina Teixeira Magalhães-Guedes ${ }^{2}$, Rosane Freitas Schwan ${ }^{2}$ \\ ${ }^{1}$ Departamento de Ciência de Alimentos, Universidade Federal de Lavras, Lavras, MG, Brazil. \\ ${ }^{2}$ Departamento de Biologia, Universidade Federal de Lavras, Lavras, MG, Brazil.
}

Submitted: November 21, 2014; Approved: March 30, 2015.

\begin{abstract}
Bacaba chicha is a beverage prepared by the indigenous Umutina people from the bacaba fruit (Oenocarpus bacaba), a purple berry that is rich in fat and carbohydrates, as well as a source of phenolic compounds. In this study, samples of bacaba chicha beverage were collected, and the microbial community was assessed using culture-dependent and -independent techniques. The nutritional composition and metabolite profiles were analyzed, and species belonging to lactic acid bacteria (LAB) and yeasts were detected. The LAB group detected by culture-dependent analysis included Enterococcus hormaechei and Leuconostoc lactis. Polymerase chain reaction and denaturing gradient gel electrophoresis (PCR-DGGE) detected additional Propionibacterium avidum, Acetobacter spp., and uncultured bacteria. Pichia caribbica and Pichia guilliermondii were detected in a culture-dependent method, and Pichia caribbica was confirmed by PCR-DGGE analysis. The $\mathrm{pH}$ value of the beverage was 6.2. The nutritional composition was as follows: $16.47 \pm 0.73{\mathrm{~g} 100 \mathrm{~mL}^{-1} \mathrm{dry}}^{-1}$

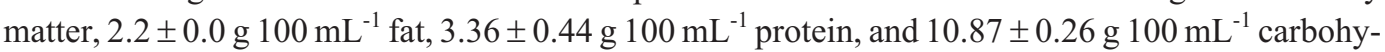
drate. The metabolites detected were $2.69 \mathrm{~g} \mathrm{~L}^{-1}$ succinic acid, $0.9 \mathrm{~g} \mathrm{~L}^{-1}$ acetic acid, $0.49 \mathrm{~g} \mathrm{~L}-1$ citric acid, $0.52 \mathrm{~g} \mathrm{~L}^{-1}$ ethanol, and $0.4 \mathrm{~g} \mathrm{~L}^{-1}$ glycerol. This is the first study to identify microbial diversity in bacaba chicha spontaneous fermentation. This study is also the starting step in the immaterial record of this Brazilian indigenous beverage prepared from bacaba fruit.
\end{abstract}

Key words: non-alcoholic beverage, indigenous beverage, lactic acid bacteria, yeasts, bacaba.

\section{Introduction}

Bacaba (Oenocarpus bacaba Mart.), a native palm found in the Brazilian Amazon and Cerrado (Brazilian Savannah) biomes, produces edible purple berries that ripen between December and April. The fruits are collected in the extractive system by indigenous and river communities and are used for feeding as a natural juice or processed into fermented beverages, jelly, and ice cream.

The Umutina indigenous people, who live in the city of Barra do Bugres in the state of Mato Grosso, Brazil, traditionally collect bacaba fruit in the forest and use this substrate to make a beverage called bacaba chicha. The beverage is also known as bacaba wine or bacaba milk, as the crushed bacaba almonds, prepared with water, produce a beverage that is creamy/light brown in color and has a pleasant taste, similar to açai (Euterpe oleracea) (ISA, 2009).

Chicha can be prepared using several cereals and fruits obtained by spontaneous fermentation, or drunk just after preparation (non-fermented) (Vallejo et al., 2013). The Umutina people make chicha using bacaba, pumpkin, rice, corn, sweet corn, and maniva.

The mesocarp of bacaba is rich in fat, carbohydrates,

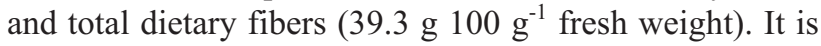
also a good source of unsaturated fatty acids, with a profile similar to that of olive oil. The total soluble solid of bacaba fruits is $7.89^{\circ} \mathrm{B}$ and $\mathrm{pH} 5.3-4.8$, with a gross energy value of $606.3 \pm 12.8 \mathrm{kcal}^{100 \mathrm{~g}^{-1}}$ fresh weight. In addition, bacaba is a promising source of phenolic compounds; it has a high anthocyanin content and significant antioxidant capacity (Abadio Finco et al., 2012). 
In spontaneous cereal-based fermentations is usually observed an association between lactic acid bacteria (LAB) and yeast, since yeast growth is favored by the acidification. The bacterial species are belonging to the genera Lactobacillus, Bacillus, Leuconostoc, Enterococcus, Streptomyces, Enterobacter, Acinetobacter, Escherichia, Cronobacter, Klebsiella, Bifidobacterium and Propioniobacterium. The yeasts species are from the genera Candida, Saccharomyces, Rhodotorula, and Pichia (Almeida et al., 2007; Schwan et al., 2007; Ramos et al., 2010; Miguel et al., 2012; Santos et al., 2012; Freire et al., 2013).

Considering the nutritional profile and the potentially functional properties of bacaba, its consumption must be stimulated between local communities, as the fruits are widely available and help low-income populations achieve rich and healthful nutrition. Because there is a tendency in these populations to consider industrial preparations superior to Brazilian foods, it is important to demonstrate the value of Brazilian produce to ensure an ideal intake of healthy food (Abadio Finco et al., 2012). There is no industrial production of bacaba chicha beverage in Brazil.

This is the first study to identify the microbial diversity in bacaba chicha spontaneous fermentation and to document the processing techniques and the biochemical composition of this beverage. Such information will support the selection of starter cultures and the future production, in laboratories and on an industrial scale, of this traditional beverage of Brazilian Amerindians. This study is important for promoting the appreciation of and safeguarding this Brazilian indigenous beverage as an immaterial cultural heritage.

\section{Materials and Methods}

\section{Bacaba chicha beverage production and sample collection}

The bacaba fruits were collected in the indigenous Umutina land a day before beverage preparation. The fruits were washed with boiled water. Figure 1 depicts the production of the bacaba beverage. The first step in the preparation of the beverage entailed selecting the fruit, adding enough boiled water to cover the fruit, and letting it stand for half an hour. The water was then changed and the fruit was immediately soaked with wood pestle. The skins were crushed, after which more water was added and a sieve was used to remove the skins and seeds. Sugar cane was added and the substrates were mixed. The beverage can be consumed immediately or after allowing it to ferment for a few hours. The time between harvesting the fruits and preparing the beverage was approximately $30 \mathrm{~h}$.

Samples of the ready bacaba beverage were taken in duplicate. Sequential tenfold dilutions in $0.1 \%$ peptone ( $0.1 \%$ peptone; HiMedia, Mumbai, India and $0.5 \% \mathrm{NaCl}$; Merck, Darmstadt, Germany) were prepared to quantify the microbial groups. Undiluted samples $(50 \mathrm{~mL})$ were taken in duplicate for $\mathrm{pH}$ and soluble solid determination, highpressure liquid chromatography (HPLC) analysis, DNA extraction, and centesimal composition.

\section{Culture-dependent microbiological analyses}

\section{Enumeration and isolation of microorganisms}

After mixing the sample in a Stomacher ${ }^{\circledR} 80$ Biomaster, for $60 \mathrm{~s}$, tenfold dilutions in saline peptone water $\left(10^{-2}-10^{-6}\right)$ were prepared and spread in duplicate on nutrient agar (Merck, Darmstadt, Germany) to perform an aerobic mesophilic bacterial count; on de Man, Rogosa \& Sharpe (MRS) agar (Merck, Darmstadt, Germany) containing $0.1 \%$ nystatin (Sigma, St. Louis, EUA) for LAB; violet

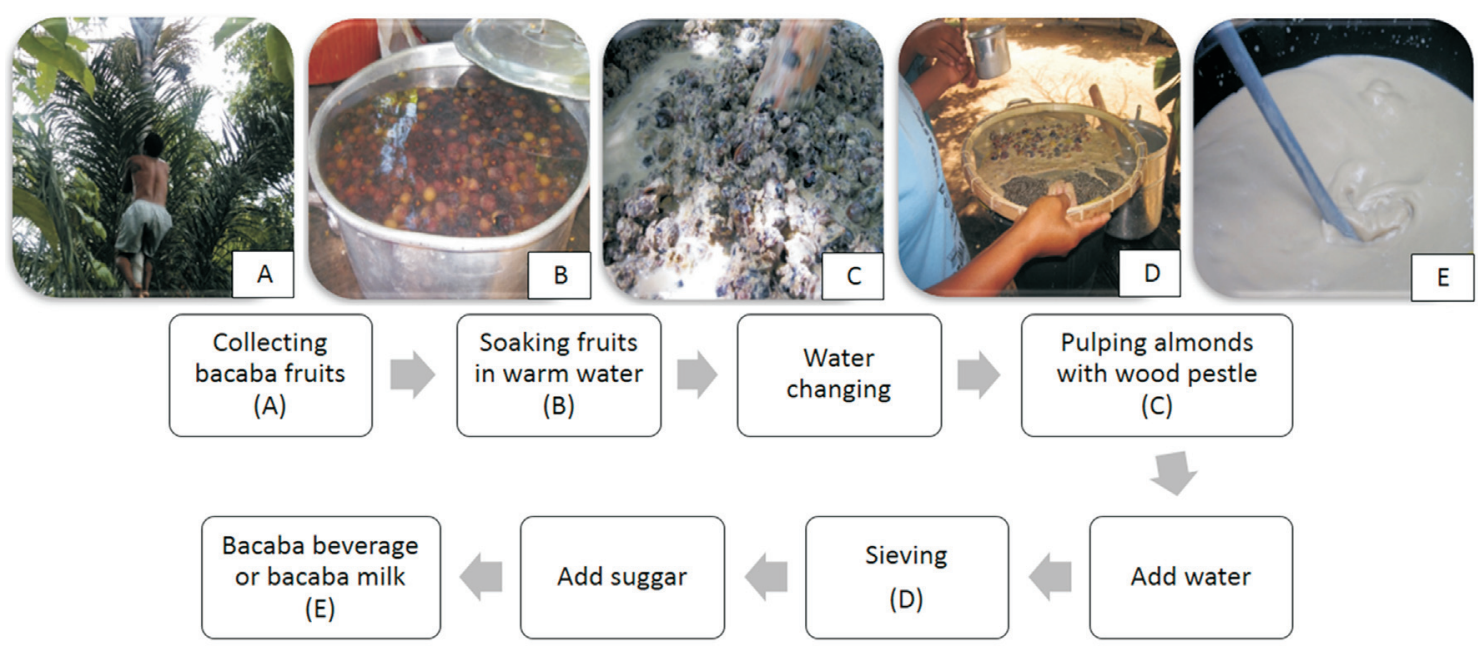

Figure 1 - Photographs and flow diagram representing the bacaba chicha beverage preparation. 
red bile glucose (VRBG) agar (Oxoid, Hampshire, England) for Gram-negative bacteria; and yeast extract peptone glucose (YEPG) agar (Merck, Darmstadt, Germany), $\mathrm{pH}$ 3.5 for yeast count. The plates were incubated aerobically at $28^{\circ} \mathrm{C}$ for $48 \mathrm{~h}$ and 5 days for bacteria and yeasts, respectively. Based on macroscopic observations, the square root of the total colonies was randomly chosen. The isolates were morphologically identified, purified, and preserved in YEPG broth with $20 \%$ glycerol at $-20{ }^{\circ} \mathrm{C}$ for further identification.

\section{Phenotypic and genotypic characterization of isolates}

The purified isolates were examined by cell morphology, and Gram stain, catalase, oxidase, motility, and sporulation tests were performed as recommended in Bergey's Manual of Determinative Bacteriology (Holt et al., 1994) and The Prokaryotes (Hammes and Hertel, 2003). The isolates were grouped according to their features and subjected to further biochemical testing.

The Gram-negative strains were identified using Bac tray kits I, II (oxidase negative), and III (oxidase positive) (Laborclin, Paraná, Brazil), according to the manufacturer's instructions. The Bac tray software for Enterobacter identification (Laborclin) was used to interpret the results.

Gram-positive bacteria were identified according Magalhães et al. (2010). Gram-positive bacteria were divided in spore-formers and non-spore-formers. Gram-positive, non-spore-forming, catalase-negative and oxidasenegative rods and cocci were presumptively classified as $\mathrm{LAB}$ and thus were classified as obligately homofermentative, facultatively heterofermentative, and obligatory heterofermentative by their ability to produce $\mathrm{CO}_{2}$ from glucose. Biochemical characterization was performed by measuring urease activity, as well as with the gelatinase test, the Triple Sugar and Iron (TSI) test, and the VogesProskauer (VP) test. Each isolate was also tested for the ability to ferment carbohydrates.

\section{REP-PCR analyses}

Following the preliminary phenotypic characterization, molecular biology-based grouping of the isolates was performed using repetitive extragenic palindromic (REP)PCR. The bacterial DNA from pure cultures was extracted using a $20 \mu \mathrm{L}$ aliquot of ultra-pure water added to the pellet. DNA was quantified to $60 \mathrm{ng}$. The suspension was then subjected to a $90{ }^{\circ} \mathrm{C} / 15 \mathrm{~min}$ thermocycling program and REP-PCR according de Melo Pereira et al. (2012). The extracts were used for PCR without further processing. RepPCR (GTG5-primer) was carried. Amplification products were separated by electrophoresis on a $1.8 \%(\mathrm{w} / \mathrm{v})$ agarose gel at $70 \mathrm{~V}$ for $4 \mathrm{~h}$ and stained with SYBR Green (Invitrogen, Foster City, CA, USA). DNA fragments were visualized by UV transillumination, and images were captured using a Polaroid camera. A ladder marker (GeneRuler 100 bp DNA Ladder Plus) was used as a size reference. The
REP-PCR profiles were normalized, and a cluster analysis was performed using BioNumerics ${ }^{\circledR}$ v.6.6 software (Applied Maths, Belgium). The dendrogram was calculated on the basis of Dice's coefficient of similarity with the unweighted pair group method with the arithmetic averages (UPGMA) clustering algorithm. Based on the phenotypic and genotypic grouping, representative isolates were selected and subjected to sequencing according de Melo Pereira et al. (2012).

\section{Culture independent analysis: PCR-DGGE}

Total DNA was extracted from the samples of bacaba chicha beverage using a QIAamp DNA kit (Qiagen, EUA) according to the manufacturer's instructions. To conduct the DGGE analyses, the PCR products from the microbial community were analyzed using a Bio-Rad DCode universal mutation detection system (Bio-Rad, Richmond, CA). Table 1 presents information regarding the primers and PCR-DGGE conditions. Aliquots $(2.0 \mu \mathrm{L})$ of the amplification products were analyzed by electrophoresis on $0.8 \%$ agarose gels before they were subjected to DGGE according de Melo Pereira et al. (2012). The gels were visualized via UV transillumination. Individual bands in the DGGE profiles were excised and amplified to provide a template for sequencing. The conditions for amplification were the same as those described for DGGE analysis, using the same primer without the GC clamp. The new PCR products were purified using a QIAEX $^{\circledR}$ III purification kit (Qiagen, Chatsworth, CA), following the manufacturer's protocol. The PCR products were sequenced by UNESP, Jaboticabal, São Paulo. The sequences were then compared to the GenBank database using the BLAST algorithm (NCBI).

\section{Physicochemical, metabolite, and nutritional composition}

The $\mathrm{pH}$ was measured according to the methodology proposed by the Association of Official Analytical Chemists (AOAC) International, at room temperature, using a digital pH meter (Micronal B474 model, São Paulo, Brazil) (AOAC, 2000).

Moisture, dry matter, fat, and ash content were determined according to the methodology proposed by AOAC (2000). Total nitrogen content was determined using the Kjeldahl method, and crude protein content was calculated using the conversion factor 6.25 . The concentration of carbohydrates was determined as $100-(\%$ moisture $+\%$ protein $+\%$ fat $+\%$ ash content), and energy value was calculated using the Atwater method (Wisker and Feldheim, 1990).

The concentrations of alcohols (ethanol, glycerol, and methanol), organic acids (oxalic, citric, tartaric, malic, succinic, propionic, butyric, acetic, and lactic), and carbohydrates (glucose, sucrose, fructose, maltose, and raffinose) were determined by HPLC according Duarte et al. (2010) using a Jasco chromatograph equipped with a refractive index (RI) detector (Jasco 830-RI, Madrid, Spain) and UV- 
Table 1 - DGGE-PCR primers used to detect the microorganisms in bacaba chicha beverage.

\begin{tabular}{|c|c|c|c|c|c|}
\hline Primer & Sequence $\left(5^{\prime}-3^{\prime}\right)$ & Community & Target & PCR conditions & References \\
\hline $338 \mathrm{fGC}$ & GCA CGC GGG GAC TCC TAC GGG AGG CAG CAG & Bacteria & V3 region of the $16 \mathrm{~S}$ & 1 & a \\
\hline $518 \mathrm{r}$ & ATT ACC GCG GCT GCT GG & & rRNA gene & & \\
\hline $27 \mathrm{fGC}$ & AGA GTT TGA TCC TGG CTC AG & Bacteria & 16S rRNA gene & 2 & \\
\hline $1512 \mathrm{r}$ & ACG GCT ACC TTG TTA CGA CT & & & & \\
\hline NS3fGC & GCA AGT CTG GTG CCA GCA GCC & Yeast & $18 \mathrm{~S}$ region of the rDNA & 3 & $\mathrm{~b}$ \\
\hline YM951r & TTG GCA AAT GCT TTC GC & & & & \\
\hline ITS1fGC & TCC GTA GGT GAA CCT GCG G & Yeast & ITS region & 4 & \\
\hline ITS4r & TCC TCC GCT TAT TGA TAT GC & & & & \\
\hline
\end{tabular}

GC clamp CGC CCG CCG CGC GCG GCG GGC GGG GCG GG; $f$ forward primer, $r$ reverse primer.

PCR Condition 1 - denatured for 5 min at $95^{\circ} \mathrm{C} ; 30$ cycles; denaturing at $92{ }^{\circ} \mathrm{C} / 1 \mathrm{~min}$; annealing at $55^{\circ} \mathrm{C} / 1 \mathrm{~min}$ and extension at $72{ }^{\circ} \mathrm{C} / 1 \mathrm{~min}$; final extension at $72{ }^{\circ} \mathrm{C} / 10 \mathrm{~min}$.

PCR Condition 2 - denatured for 5 min at $94{ }^{\circ} \mathrm{C} ; 30$ cycles; denaturing at $94{ }^{\circ} \mathrm{C} / 40 \mathrm{~s}$; annealing at $52{ }^{\circ} \mathrm{C} / 1 \mathrm{~min}$ and extension at $72{ }^{\circ} \mathrm{C} / 1 \mathrm{~min}$; final extension at $72{ }^{\circ} \mathrm{C} / 7 \mathrm{~min}$.

PCR Condition 3 - denatured for $5 \mathrm{~min}$ at $95^{\circ} \mathrm{C} ; 35$ cycles; denaturing at $95{ }^{\circ} \mathrm{C} / 1 \mathrm{~min}$; annealing at $50{ }^{\circ} \mathrm{C} / 1 \mathrm{~min}$ and extension at $72{ }^{\circ} \mathrm{C} / 1 \mathrm{~min}$; final extension at $72{ }^{\circ} \mathrm{C} / 7 \mathrm{~min}$.

PCR Condition 4 - denatured for $5 \mathrm{~min}$ at $95{ }^{\circ} \mathrm{C} ; 30$ cycles; denaturing at $95{ }^{\circ} \mathrm{C} / 30 \mathrm{~s}$.; annealing at $52{ }^{\circ} \mathrm{C} / 30 \mathrm{~s}$ and extension at $72{ }^{\circ} \mathrm{C} / 1 \mathrm{~min}$. final extension at $72{ }^{\circ} \mathrm{C} / 10 \mathrm{~min}$.

a - Øvreås et al., 1997.

b - Haruta et al., 2006.

Visible detector (Jasco 870-UV-visible). A Chrompack column $(300 \mathrm{~mm} \times 6.5 \mathrm{~mm})$ at $60^{\circ} \mathrm{C}$, using $5 \mathrm{mM}$ sulphuric acid as the eluent, at a flow rate of $0.5 \mathrm{~mL} \mathrm{~min}^{-1}$ and a sample volume of $20 \mu \mathrm{L}$ was used.

\section{Results and Discussion}

\section{Microbial identification by culture-dependent/independent methods}

The bacaba chicha beverage contained similar mesophilic bacteria, $\mathrm{LAB}$, and a yeast population in quantities of 4.8, 4.9, and $4.8 \log$ cfu $\mathrm{mL}^{-1}$, respectively. The Gramnegative bacteria population was lower, at $3.3 \log \mathrm{cfu} \mathrm{mL}^{-1}$.

The 543 bacterial and 279 yeast isolates were biochemically classified and grouped by REP-PCR using BioNumerics (Figure 2 and 3). Considering the patterns obtained, 51 bacterial and 26 yeast isolates were submitted to DNA-sequencing analysis. Gram-positive bacteria dominated the microbiota. The sequencing of $42 \mathrm{Gram}$-positive isolates revealed two genera belonging to the LAB group-Enterococcus spp. $(\mathrm{n}=39)$ and Leuconostoc spp. $(\mathrm{n}=3)$. Phylogenetic analysis of the 16S rRNA gene showed that these isolates were closely related to Enterococcus durans, the dominant bacteria, E. hirae, and Leuconostoc lactis ( $99 \%$ similarity). Enterococcus spp. are found in human feces and appear in soil, surface water, plants, and vegetables. This genera is found in dairy product fermentation and fermented sausages and olives (Ong et al., 2012). LAB metabolism contributes to flavor promotion and beverage preservation. Enterococcus is reported to be responsible for contributing to flavor development, probably through proteolysis, lipolysis, and citrate breakdown (Foulquié Moreno et al., 2006; Shori, 2012).
Representative Gram-negative bacteria isolated from the bacaba beverage were tested and grouped according to morphological and biochemical features. The sequencing of representative isolates by REP-PCR identified four isolates as belonging to the genus Enterobacter, with high similarity to E. hormaechei, and three isolates were identified as Pantoea dispersa.

Enterobacter, a member of the Enterobacteriaceae family, is a ubiquitous bacterium that adapts to a wide variety of environments and can be isolated from different sources and foods, such as infant formula, cereal products, milk powder, environmental samples (Shaker et al., 2007), Chinese liquor (Zheng et al., 2012), grapes (Barata et al., 2012), and sobia, a wheat and malt beverage (Gassem, 2002). E. hormaechei has been isolated from inyu, a Taiwanese soy sauce (Wei et al., 2013). It is not possible to determine whether the presence of Enterobacter in bacaba fruits is due to contamination from the environment or as a constituent of endophytic populations, as reported in strawberries (de Melo Pereira et al., 2012).

The yeast population was composed mainly of Pichia caribbica $(\mathrm{n}=19)$, and in lower numbers, Pichia guilliermondii $(\mathrm{n}=8)$. Yeasts are frequently isolated from fruit surfaces, with populations ranging from 2 to $6 \log$ $\mathrm{cfu} / \mathrm{g}^{-1}$ on apples, grapes, strawberries, and masau fruit (Nyanga et al., 2007). Pichia spp. typically form films on liquid media and are known to be important in producing indigenous foods in various parts of the world. Pichia is frequently found on grape surfaces, growing during the initial stage of wine fermentation (Urso et al., 2008; Stringini et al., 2009; Chavan et al., 2009; Li et al., 2010) and in rice wine (Lv et al., 2012). Pichia spp. are normally present at the beginning of wine fermentation, mainly in damaged rip- 


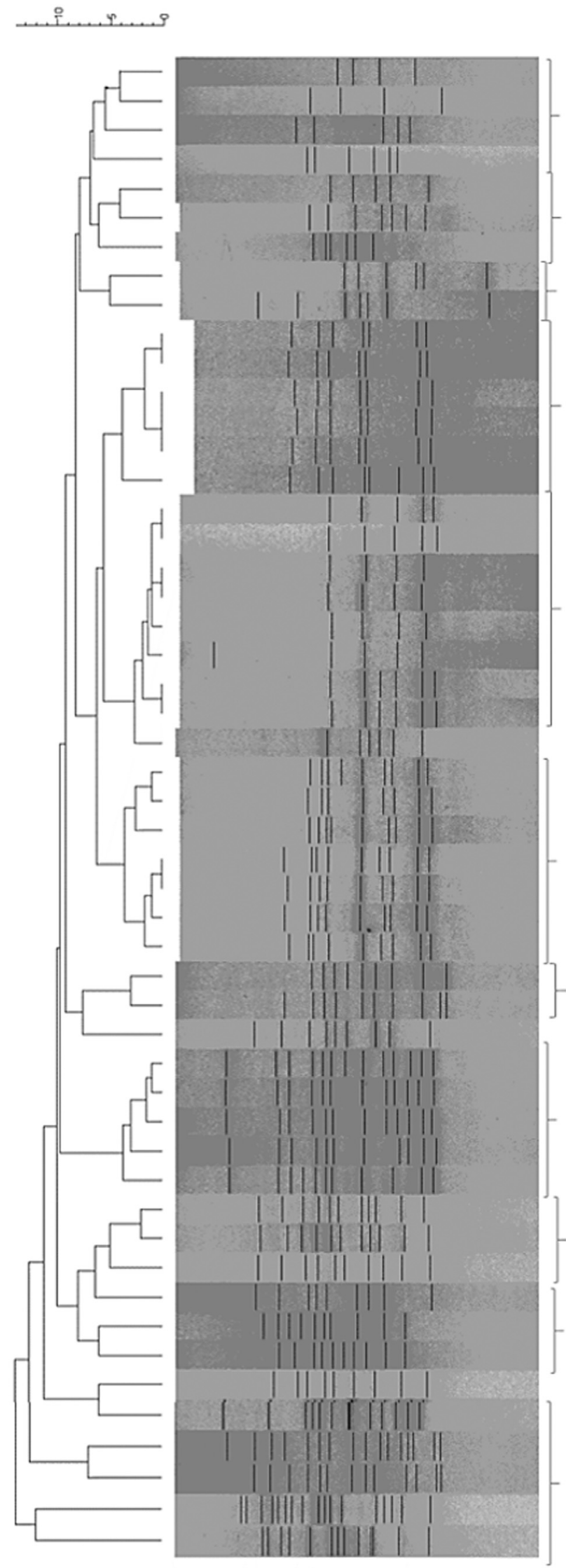

Enterococcus durans

Enterococcus durans

Enterococcus durans

Enterococcus durans

Leuconostoc lactis

Leuconostoc lactis

Leuconostoc lactis

Enterococcus hirae

Enterococcus hirae

Enterococcus dirans

Enterococcus durans

Enterococcus diurans

Enterococcus diurans

Enterococcus durans

Enterococcus ditrons

Enterococcus durans

Enterococcus durans

Enterococcus durans

Enterococcus durans

Enterococcus durans

Enterococcus durans

Enterococcus durans

Enterococcus durans

Unidentified specie

Enterococcus durans

Enterococcus durans

Enterococcus durans

Enterococcus durans

Enterococcus durans

Enterococcus durans

Enterococcus durans

Enterococcus durans

Enterococcus durans

Unidentified specie

Enterococcus durans

Enterococcus durans

Enterococcus durans

Enterococcus durans

Enterococcus durans

Enterobacter hormaechei

Enterobacter hormaechel

Enterobacter hormaechei

Pantoea dispersa

Pantoea dispersa

Pantoea dispersa

Enterobacter hormaechet

Enterococcus ditrans

Enterococcus durans

Enterococcus durans

Enterococcus durans

Enterococcus durans

Figure 2 - Dendrogram generated after cluster analysis of Rep-PCR bacterial DNA fingerprints in bacaba chicha beverage. 
ened fruits, when the sugar is more available (Barata et al., 2012). Chanprasartsuk et al. (2010) reported $H$ Hanseniaspora uvarum and $P$. guilliermondii as the main species isolated from freshly crushed pineapple juice and natural fermented wine from Thailand and Australia, but Saccharomyces yeasts were not found.

The association of yeast and LAB bacteria found in bacaba preparations has also been described in several other fermented foods produced from cassava, rice, peanuts, and fruit (Caplice and Fitzgerald, 1999; Gassem, 2002; Almeida et al., 2007; Schwan et al., 2007; Wilfrid Padonou et al., 2009; Ramos et al., 2010; Chadare et al., 2010; Miguel et al., 2012; Freire et al., 2013). Stringini et al. (2009) verified this association in a West African palm wine, and Nyanga et al. (2007) found an association between LAB and yeast in masau fruit and fermented fruit pulp.
LAB contributes to beverage fermentation by acidification (McDonald et al., 1990), and flavor development is a result of LAB and yeast activity. Yeasts can produce volatile compounds and metabolites that improve the flavor properties of the final product and enhance LAB growth by the release of nutritive compounds (Tofalo et al., 2012).

Figure 4 shows the DGGE profile obtained after amplification of the $\mathrm{V} 3$ region of bacterial 16S rRNA and $18 \mathrm{~S}$ and ITS region of fungal rDNA, obtained directly from the samples. The bands showed the presence of Enterococcus spp. and Enterobacter spp., as detected by REP-PCR, and uncultured bacteria. The DGGE assessment revealed the further presence of Propionibacterium avidum and Acetobacter spp.

PCR-DGGE was not able to detect the Leuconostoc species. It should be pointed out that the cell numbers of those species fell below the detection limit of PCR-DGGE $\left(10^{3} \mathrm{cfu} \mathrm{mL}^{-1}\right)($ Cocolin et al., 2001). The PCR-DGGE pro-

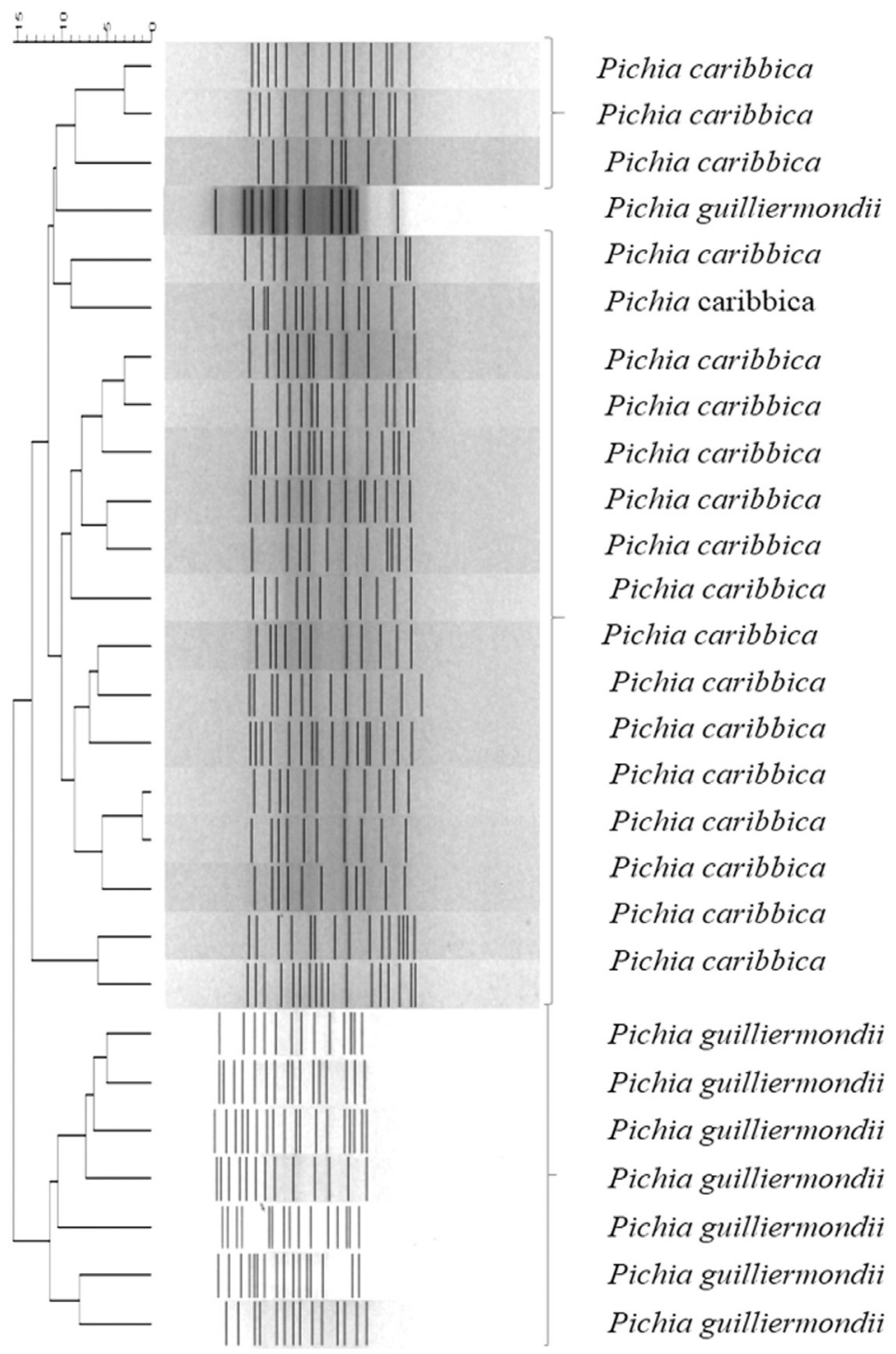

Figure 3 - Dendrogram generated after cluster analysis of Rep-PCR yeast DNA fingerprints in bacaba chicha beverage. 


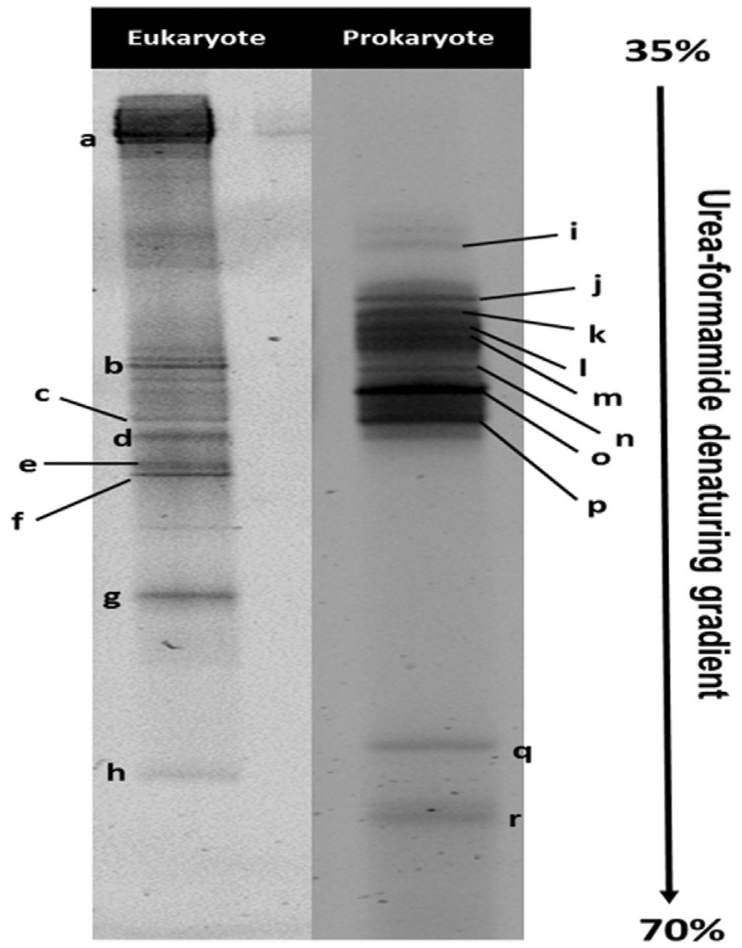

Identical profiles were obtained for the following primers pairs: Eukaryote (NS3fGC/YM951r and ITS1fGC/ITS4r) Prokaryote (338fGC/518r and $27 \mathrm{fGC} / 1512 \mathrm{r})$

Figure 4 - PCR-DGGE profiles of the Eukaryote and Prokaryote communities in bacaba chicha beverage. Eukaryote: The closest relatives of the fragments sequenced, based on a search of GenBank ( $>99 \%$ similarity), were bands a - uncultured Eukaryote; b - Pichia caribbica; c - uncultured Malassezia; d - uncultured Eukaryote; e - not sequenced; f - uncultured Eukaryote; g - not sequenced; h - not sequenced. Prokaryote: The closest relatives of the fragments sequenced, based on a search of GenBank ( $>$ 97\% similarity), were bands: $\mathrm{i}$ - not sequenced; $\mathrm{j}$ - not sequenced; $\mathrm{k}$ Propionibacterium avidum; 1 - Enterococcus spp.; $\mathrm{m}$ - uncultured bacteria; n - Enterobacter spp.; o - Acetobacter spp.; p - uncultured bacteria; q - not sequenced; $r$ - uncultured bacteria.

file of fungal DNA extracted directly from the samples was composed mainly of Pichia caribbica and others uncultured eukaryotes.

Conventional microbiological methods, which require selective enrichments and sub-culturing, are dependent on the ability of a microorganism to grow on the medium under the culturing conditions applied, on the number of isolates, and on the selection methodology. Thus, those methods might fail to detect some microorganisms, excluding members of the microbial community (Jany and Barbier, 2008; Magalhães et al., 2010). Culture-independent approaches have the advantage of being able to reveal microorganisms that are difficult or impossible to culture (Quigley et al., 2011).

\section{Chemical composition of bacaba chicha beverage}

The $\mathrm{pH}$ value of the final beverage was 6.2. The organic acids that were present were probably the result of yeast and bacteria metabolism during the preparation time, when the fruit rested in warm water. Organic acid concentration was low, and therefore not enough to reduce the $\mathrm{pH}$.

From a nutritional point of view, the bacaba fruit

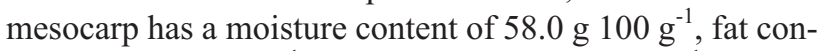

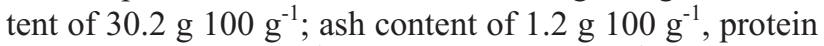

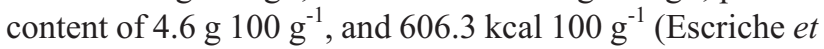
al., 1999). The bacaba beverage exhibited an energy value of $76.7 \mathrm{kcal} 100 \mathrm{~mL}^{-1}$. The macronutrient composition con-

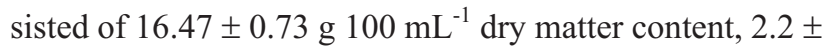

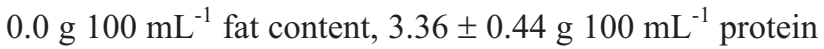
content, and $10.87 \pm 0.26 \mathrm{~g} 100 \mathrm{~mL}^{-1}$ carbohydrate content (Table 2). The high carbohydrate content reflects the added sugar. The soluble protein content was considerably higher than that reported in caxiri $(1.0 \%)$ and corn and rice calugi (1.53\%) (Miguel et al., 2012; Santos et al., 2012).

The indigenous Huitoto, Andoque, Yukuna, Muinane, and Miraña tribes that settled in the Amazon region of Colombia consume the bacaba fruit mesocarp in the form of chicha or cahuana, contributing a substantial amount of fat and carbohydrate to their diet (Escriche et al., 1999).

A spontaneous fermentation occurred when the fruit rested in warm water, it underwent three types of spontaneous fermentation, confirmed by HPLC results: alcoholic, succinic, and acetic (Figure 5). The metabolic compounds verified in the bacaba beverage occurred because the long postharvest period stimulates spontaneous fermentation. Considering that the first preparation step consists of placing the fruit in warm water for half an hour, the increased water content, the availability of nutrients, and the temperature created ideal conditions for the natural microorganisms present on the fruit surface and environment to grow. A specific microbiota produced metabolic compounds and modifying the taste and smell of the beverage. These microbial communities vary in composition and diversity according to a range of environmental factors, including $\mathrm{pH}$, sugars, moisture availability, fruit growing conditions, and transport and storage procedures (Nyanga et al., 2007; Aguiar et al., 2013; Leff and Fierer, 2013). The spontaneous postharvest fermentation is also favored by intrinsic

Table 2 - Nutritional composition of bacaba chicha beverage.

\begin{tabular}{lc}
\hline Nutrient & Composition $\left(\mathrm{g} 100 \mathrm{~mL}^{-1} \pm \mathrm{DP}\right)$ \\
\hline Moisture & $83.58 \pm 0.70$ \\
Dry matter & $16.47 \pm 0.73$ \\
Ash & $0.18 \pm 0.0$ \\
Fat & $2.20 \pm 0.0$ \\
Fiber & $1.68 \pm 0.13$ \\
Protein $(\mathrm{N} \times 6.25)$ & $3.36 \pm 0.44$ \\
Carbohydrate & $10.87 \pm 0.26$ \\
Energy (kcal $\left.100 \mathrm{~mL}^{-1}\right)$ & 76.70 \\
\hline
\end{tabular}

Values are means \pm SD for triplicate analys. 


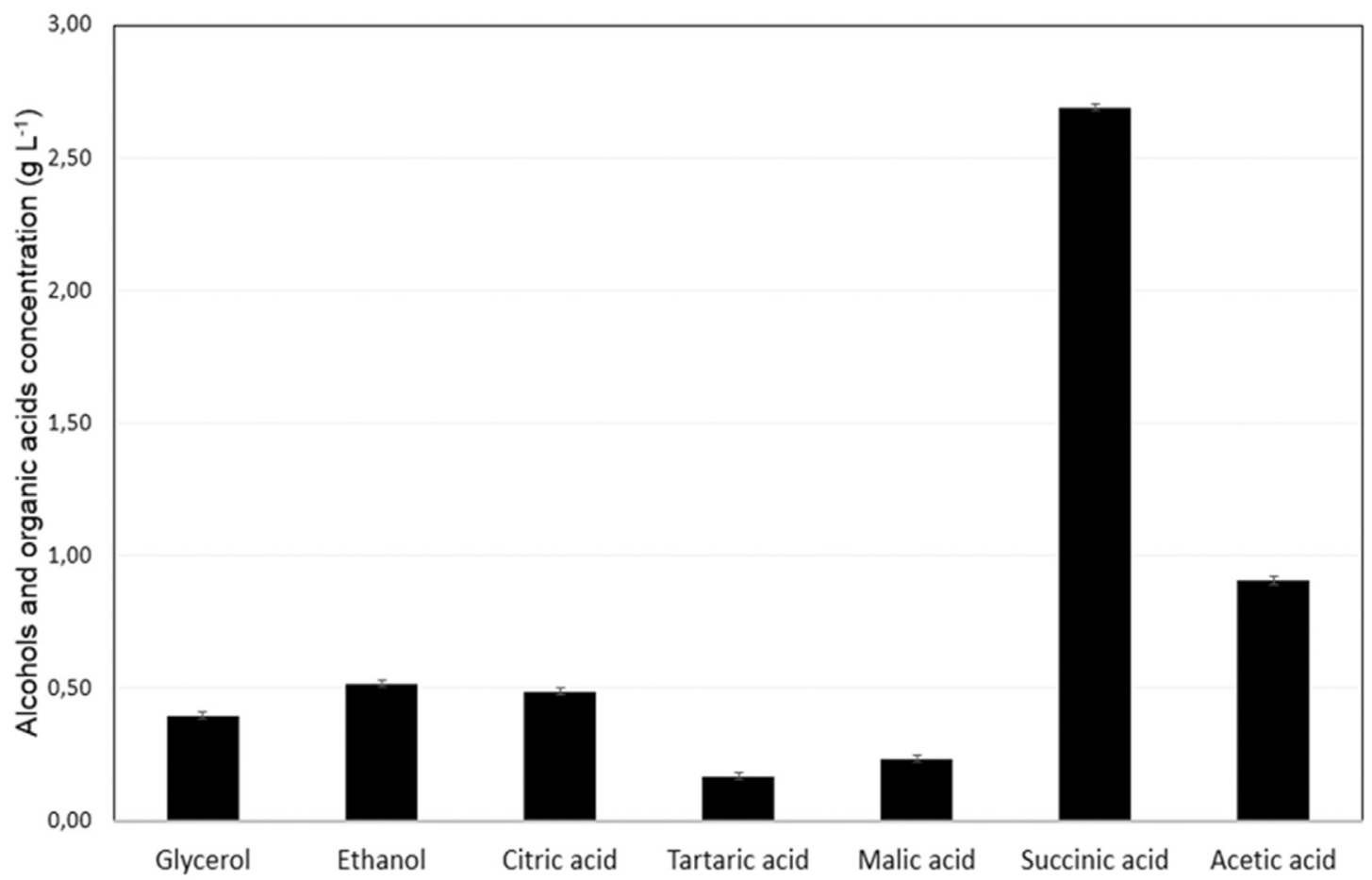

Figure 5 - Organic acids and alcohols production by natural microbiota in bacaba chicha beverage.

and extrinsic factors such as $\mathrm{pH}$ (3-5), sugar content, and the respiratory activity of the fruit, which turn the environment anaerobic and prone to fermentation (Aguiar et al., 2013).

The concentration of succinic acid $\left(2.69 \mathrm{~g} \mathrm{~L}^{-1}\right)$, acetic acid $\left(0.9 \mathrm{~g} \mathrm{~L}^{-1}\right)$, and citric acid $\left(0.49 \mathrm{~g} \mathrm{~L}^{-1}\right)$ was due to the microbiota metabolism (LAB and yeast) during the first step of the bacaba beverage production. Acetic acid in higher concentrations is generally considered an undesirable metabolite in fruit wines (Barata et al., 2012; Duarte et al., 2010). Malic and tartaric acid were present in lower concentrations, but other acids (lactic, oxalic, propionic, and butyric) were not detected by HPLC. The sugars present in the beverage and the respective concentrations $\left(\mathrm{g} \mathrm{L}^{-1}\right)$ were fructose $(3.62 \pm 0.3)$, glucose $(4.0 \pm 0.9)$, and sucrose $(88.4 \pm 1.0)$. The sucrose was added during the preparation of the beverage. Maltose and raffinose were not found.

Ethanol was present at a low level $\left(0.52 \mathrm{~g} \mathrm{~L}^{-1}\right)$ and the glycerol content was $0.4 \mathrm{~g} \mathrm{~L}^{-1}$; they are the main products of fermentative yeasts. High temperatures $\left(19-31^{\circ} \mathrm{C}\right)$ increase ethanol production (Zajsek and Gorsek, 2010). The ambient temperature in the Umutina region during the beverage production ranged from $30^{\circ}$ to $35^{\circ} \mathrm{C}$. Methanol was not identified. Due to the low ethanol content, the bacaba beverage was classified as a non-alcoholic beverage.

\section{Conclusion}

This study represents the first attempt to examine the bacaba chicha beverage. The microbiological results indi- cated that the better microbial community description could be reached when using culture-dependent and culture-independent methods together. The study of the chemical composition and the metabolite changes helped in understanding the nutritional importance of the bacaba beverage to the Umutina people and in validating its consumption, as bacaba fruit is widely available and has high nutritional value. This study is important for promoting the appreciation of and safeguarding this Brazilian indigenous beverage as an immaterial cultural heritage.

\section{Acknowledgments}

Coordenação de Aperfeiçoamento de Pessoal de Nível Superior (CAPES), Conselho Nacional de Desenvolvimento Científico e Tecnológico (CNPq), and Fundação de Amparo à Pesquisa do Estado de Minas Gerais (FAPEMIG) are acknowledge for their financial support.

\section{References}

Abadio Finco FDB, Kammerer DR, Carle R et al. (2012) Antioxidant activity and characterization of phenolic compounds from bacaba (Oenocarpus bacaba Mart.) fruit by HPLCDAD-MS(n). J Agricult Food Chem 60:7665-7673.

Aguiar F, Menezes V, Rogez H (2013) Spontaneous postharvest fermentation of açai (Euterpe oleracea) fruit. Postharv Biol Technol 86:294-299.

Almeida EG, Rachid CCTC, Schwan RF (2007) Microbial population present in fermented beverage "cauim" produced by Brazilian Amerindians. Inter J Food Microbiol 120:146151. 
AOAC - Association of Official Analytical Chemist (2000) Official Methods of Analysis of the Association of Official Analytical Chemist. 17th ed. AOAC, Washington.

Barata A, Malfeito-Ferreira M, Loureiro V (2012) The microbial ecology of wine grape berries. Inter J Food Microbiol 153:243-259.

Caplice E, Fitzgerald, GF (1999) Food fermentations: role of microorganisms in food production and preservation. Inter $\mathbf{J}$ Food Microbiol 50:131-149. Retrieved from http://www.ncbi.nlm.nih.gov/pubmed/10488849

Chanprasartsuk O, Prakitchaiwattana C, Sanguandeekul R et al. (2010) Autochthonous yeasts associated with mature pineapple fruits, freshly crushed juice and their ferments; and the chemical changes during natural fermentation. Biores Technol 101:7500-7509.

Chavan P, Mane S, Kulkarni G et al. (2009) Natural yeast flora of different varieties of grapes used for wine making in India. Food Microbiol 26:801-808.

Cocolin L, Manzano M, Cantoni C et al. (2001) Denaturing Gradient Gel Electrophoresis Analysis of the 16S rRNA Gene V1 Region to Monitor Dynamic Changes in the Bacterial Population during Fermentation of Italian Sausages. Appl Environ Microbiol 67:5113-5121.

De Melo Pereira GV, Magalhães KT, Lorenzetii ER et al. (2012) A multiphasic approach for the identification of endophytic bacterial in strawberry fruit and their potential for plant growth promotion. Microb Ecol 63:405-417.

Duarte WF, Dias DR, Oliveira JM et al. (2010) Characterization of different fruit wines made from cacao, cupuassu, gabiroba, jaboticaba and umbu. LWT - Food Scien Technol 43:1564-1572.

Foulquié Moreno MR, Sarantinopoulos P, Tsakalidou E et al. (2006) The role and application of enterococci in food and health. Inter J Food Microbiol 106:1-24.

Freire AL, Ramos CL, de Almeida EG et al. (2013) Study of the physicochemical parameters and spontaneous fermentation during the traditional production of yakupa, an indigenous beverage produced by Brazilian Amerindians. World J Microbiol Biotechnol 30:567-77.

Gassem MAA (2002) A microbiological study of Sobia: a fermented beverage in the Western province of Saudi Arabia. World J Microbiol Biotechnol 18:173-177.

Hammes WP, Hertel C (2003) The genus Lactobacillus. The Prokaryotes an Electronic Resource for the microbiological Community. Retrieved June 15, 2013, from http://www.prokaryotes.com.

Haruta S, Ueno S, Egawa I et al. (2006) Succession of bacterial and fungal communities during a traditional pot fermentation of rice vinegar assessed by PCR-mediated denaturing gradient gel electrophoresis. Inter J Food Microbiol 109:79-87.

Holt JG, Krieg NR, Sneath PHA et al. (1994) Bergey's manual of determinative bacteriology. Willians \& Wilkins, Baltimore.

ISA - Instituto Sócio Ambiental (2009) Umutina. Enciclopédia dos Povos Indígenas no Brasil. Retrieved January 20, 2014, from http://pib.socioambiental.org/pt/povo/umutina.

Jany JL, Barbier G (2008) Culture-independent methods for identifying microbial communities in cheese. Food Microbiol 25:839-848.
Leff JW, Fierer N (2013) Bacterial communities associated with the surfaces of fresh fruits and vegetables. PloS One 8: e59310, 01-09.

Li SS, Cheng C, Li Z et al. (2010) Yeast species associated with wine grapes in China. Inter J Food Microbiol 138:85-90.

Lv XC, Weng X, Zhang W et al. (2012) Microbial diversity of traditional fermentation starters for Hong $\mathrm{Qu}$ glutinous rice wine as determined by PCR-mediated DGGE. Food Control 28:426-434

Magalhães KT, de M Pereira GV, Dias DR et al. (2010) Microbial communities and chemical changes during fermentation of sugary Brazilian kefir. World J Microbiol Biotechnol 26:1241-1250.

McDonald LC, Fleming HP, Hassan HM (1990) Acid Tolerance of Leuconostoc mesenteroides and Lactobacillus plantarum. Appl Environ Microbiol 56:2120-2124. Retrieved from http://www.pubmedcentral.nih.gov/articlerender.fcgi?artid $=184570 \&$ tool $=$ pmcentrez\&rendertype $=$ abstract.

Miguel MGDCP, Santos MRRM, Duarte WF et al. (2012) Physico-chemical and microbiological characterization of corn and rice "calugi" produced by Brazilian Amerindian people. Food Resear Inter 49:524-532.

Nielsen DS, Teniola OD, Ban-Koffi L et al. (2007) The microbiology of Ghanaian cocoa fermentations analysed using culture-dependent and culture-independent methods. Inter J Food Microbiol 114:168-186.

Nyanga LK, Nout MJR, Gadaga TH et al. (2007) Yeasts and lactic acid bacteria microbiota from masau (Ziziphus mauritiana) fruits and their fermented fruit pulp in Zimbabwe. Inter $\mathrm{J}$ Food Microbiol 120:159-166.

Ong YY, Tan WS, Rosfarizan M et al. (2012) Isolation and identification of lactic acid bacteria from fermented red dragon fruit juices. J Food Scien 77:M560-M564.

Øvreås L, Forney L, Daae FL et al. (1997) Distribution of bacterioplankton in meromictic lake $\mathrm{S} \pm$ lenvannet, as determined by Denaturing Gradient Gel Electrophoresis of PCRAmplified Gene Fragments Coding for 16S rRNA. Appl Environ Microbiol 63:3367-3373

Quigley L, O'Sullivan O, Beresford TP et al. (2011) Molecular approaches to analysing the microbial composition of raw milk and raw milk cheese. Inter J Food Microbiol 150:8194.

Ramos CL, de Almeida EG, Pereira GVDM et al. (2010) Determination of dynamic characteristics of microbiota in a fermented beverage produced by Brazilian Amerindians using culture-dependent and culture-independent methods. Inter J Food Microbiol 140:225-231.

Santos CCAA, Almeida EG, Melo GVP et al. (2012) Microbiological and physicochemical characterisation of caxiri, an alcoholic beverage produced by the indigenous Juruna people of Brazil. Inter J Food Microbiol 156:112-121.

Schwan RF, Almeida EG, Souza-Dias MAG et al. (2007) Yeast diversity in rice-cassava fermentations produced by the indigenous Tapirapé people of Brazil. FEMS Yeast Resear 7:966-972.

Shaker R, Osaili T, Al-Omary W et al. (2007) Isolation of Enterobacter sakazakii and other Enterobacter sp. from food and food production environments. Food Control 18:1241-1245.

Shori AB (2012) Comparative study of chemical composition, isolation and identification of micro-flora in traditional fer- 
mented camel milk products: Gariss, Suusac, and Shubat. J Saudi Society Agricult Scien 11:79-88.

Stringini M, Comitini F, Taccari M et al. (2009) Yeast diversity during tapping and fermentation of palm wine from Cameroon. Food Microbiol 26:415-420.

Tofalo R, Schirone M, Perpetuini G et al. (2012) Development and application of a real-time PCR-based assay to enumerate total yeasts and Pichia anomala, Pichia guillermondii and Pichia kluyveri in fermented table olives. Food Control 23:356-362.

Urso R, Rantsiou K, Dolci P et al. (2008) Yeast biodiversity and dynamics during sweet wine production as determined by molecular methods. FEMS Yeast Resear 8:1053-1062.

Vallejo JA, Miranda P, Flores-Félix JD et al. (2013) Atypical yeasts identified as Saccharomyces cerevisiae by MALDITOF MS and gene sequencing are the main responsible of fermentation of chicha, a traditional beverage from Peru. Systematic Appl Microbiol 36:560-564.

Wei CL, Chao SH, Tsai WB et al. (2013) Analysis of bacterial diversity during the fermentation of inyu, a high-temperature fermented soy sauce, using nested PCR-denaturing gradient gel electrophoresis and the plate count method. Food Microbiol 33:252-261.

Wilfrid Padonou S, Nielsen DS, Hounhouigan JD et al. (2009) The microbiota of Lafun, an African traditional cassava food product. Inter J Food Microbiol 133:22-30.

Wisker E, Feldheim W (1990) Carbohydrate and fiber metabolizable energy of diets low or high in dietary fiber from fruits and vegetables when consumed by humans. The J Nutrit 120:331-1337.

Zajsek K, Gorsek A (2010) Mathematical modelling of ethanol production by mixed kefir grains yeast population as a function of temperature variations. Biochem Engin J 49:7-12.

Zheng XW, Yan Z, Han BZ et al. (2012) Complex microbiota of a Chinese "Fen" liquor fermentation starter (Fen-Daqu), revealed by culture-dependent and culture-independent methods. Food Microbiol 31:293-300.

Associate Editor: Elaine Cristina Pereira De Martinis

All the content of the journal, except where otherwise noted, is licensed under a Creative Commons License CC BY-NC. 